$\underline{\text { Short Report }}$

\title{
Preliminary survey of knowledge, attitudes and practices among nurses regarding seasonal influenza and influenza vaccination
}

\author{
WCR Fonseka ${ }^{1}$, GE Ganhewa ${ }^{1}$, KPB Guneratne ${ }^{1}$, AS Hapugalle ${ }^{1}$, S Nagarajah $^{1}$, \\ BCV Senaratna ${ }^{1}, \mathrm{KM}_{\text {Gunasekera }}^{2}$
}

Sri Lankan Journal of Infectious Diseases 2021 Vol.11(1):32-37

DOI: http://dx.doi.org/10.4038/sljid.v11i1.8343

\begin{abstract}
Health care workers are at risk of influenza through occupational exposure. Uptake of influenza vaccine is poor even in countries where it is provided free. We sought to determine the knowledge, attitudes and practices regarding seasonal influenza and barriers for vaccination among nurses in Colombo. A cross sectional survey was carried out from February to March 2020 on 97 randomly selected nurses. Level of knowledge was measured using a scoring system. Only a few $(n=7 ; 7.2 \%)$ nurses had been immunized against influenza. Overall knowledge regarding influenza and vaccines was average in most nurses $(n=53 ; 55 \%)$. The majority $(n=62$; $63.9 \%)$ believed the vaccine was safe and $79.4 \%(n=77)$ were willing to be vaccinated if vaccine is provided free. However, 15 of these 77 (19.5\%) were reluctant to be vaccinated annually. Identified barriers for vaccination were the perception that the vaccine was not essential, doubt about its efficacy, fear of vaccines and side effects. Knowledge should be improved, and misconceptions and fears need to be addressed through health education and promotion.
\end{abstract}

Keywords: Influenza, knowledge, attitudes, Sri Lanka, vaccine

\section{Introduction}

Influenza is of public health importance as it causes epidemics and pandemics which result in three to five million severe cases and 290,000-650,000 deaths worldwide every year. ${ }^{1}$ Respiratory illnesses are the third leading cause of hospital admissions and fourth leading cause of deaths in Sri Lanka and influenza is a major contributor. ${ }^{2}$

${ }^{1}$ Faculty of Medical Sciences, University of Sri Jayewardenepura, Sri Lanka

${ }^{2}$ Department of Microbiology, Faculty of Medical Sciences, University of Sri Jayewardenepura, Sri Lanka

Address for correspondence: KM Gunasekera, Department of Microbiology, Faculty of Medical Sciences, University of Sri Jayewardenepura, Sri Lanka Telephone no: +94718329772 E-mail: kamani@sjp.ac.lk

https://orcid.org/0000-0002-2015-2680

Received 29 December 2020 and revised version accepted 13 February 2021

(c) (i) This an open-access article distributed under the terms of the Creative Commons Attribution License, which permits unrestricted use, distribution, and reproduction in any medium, provided the original author and source are credited. 
Influenza vaccination decreases the risk of infection, morbidity and mortality in nosocomial infections. The vaccine is given annually and is recommended for high risk groups including health care workers (HCWs). HCWs have an occupational risk of acquiring influenza and can spread infection to patients and staff. Seasonal influenza vaccines have been approved for use but the government does not provide it free for HCWs in Sri Lanka. Vaccine coverage is reported to be low among HCWs, even in countries where it is provided free. ${ }^{3}$ We sought to evaluate the level of knowledge, attitudes and practices (KAP) among nurses and to identify the barriers for influenza vaccination among nurses in Sri Lanka.

\section{Methods}

We conducted a cross sectional study among nurses $(n=97)$ of a tertiary care hospital in Colombo, from February to March, 2020. A validated interviewer administered questionnaire approved by the Ethics Review Committee, Faculty of Medical Sciences, Sri Jayewardenepura, consisting of 20 open or close-ended questions was used. The questionnaire was developed in English, translated to Sinhala and Tamil and pretested in 20 participants excluded from the study. The questionnaire was administered in the preferred language of the participants. Nurses (total number in hospital 700) were recruited by systematic random sampling (sampling interval of 3.52), following informed written consent. The targeted sample size was 199.

Questions on knowledge $(n=11)$, attitude $(n=6)$ and practices $(n=2)$ were included in the questionnaire. Each correct answer scored one point and incorrect or "don't know" responses scored zero. The maximum score for knowledge was 23 and was graded as good ( $\geq 18$ points), average (13-17 points) or poor ( $\leq 12$ points) (Table 1$)$. Descriptive statistical analysis was performed using SPSS version 16.0 (SPSS Inc., USA).

\section{Table 1. Scoring system for questions}

Questions testing knowledge

Grading of scores

\begin{tabular}{llccc} 
& & Good & Average & Poor \\
\cline { 3 - 4 } $\mathbf{1}$ & Can you name 4 physical features of influenza/viral fever & 4 & 3 & $\leq 2$ \\
\hline $\mathbf{2}$ & During which months of the year do influenza outbreaks occur & 1 & - & 0 \\
\hline $\mathbf{3}$ & $\begin{array}{l}\text { Is it a mild disease or does it have complications that could lead to } \\
\text { death? }\end{array}$ & 1 & - & 0 \\
$\mathbf{4}$ & Who is at risk of severe complications from influenza? & 4 & 3 & $\leq 2$ \\
$\mathbf{5}$ & Can you name 3 methods to prevent getting Influenza yourself & 3 & 2 & $\leq 1$ \\
$\mathbf{6}$ & Mention 3 methods of transmission & 3 & 2 & $\leq 1$ \\
$\mathbf{7}$ & Can you name 3 measures that would prevent transmission to others & 3 & 2 & $\leq 1$ \\
$\mathbf{8}$ & Is there any medication for Influenza? & 1 & - & 0 \\
$\mathbf{9}$ & What are those medications? & 1 & - & 0 \\
$\mathbf{1 0}$ & Is there a vaccine for influenza? & 1 & - & 0 \\
$\mathbf{1 1}$ & How often the vaccine needs to be given? & 1 & - & 0 \\
\hline & Maximum score & 23 &
\end{tabular}




\section{Results}

Overall response rate was $80.8 \%$ (97/120). Nurses were mostly females (92.8\%), aged 24-57 (mean 35.1) years and predominantly Buddhist (96.9\%), Sinhalese (97.9\%) and married (75.3\%).

\section{Knowledge}

Level of knowledge on symptoms was good in $68 \%$ (66/97). The majority $(83.5 \%)$ were aware that influenza could lead to complications and death. Knowledge regarding high risk groups was mostly average $(n=38 ; 39.2 \%)$ (Table $2 \mathrm{a})$.

Table 2a. Proportion of responses to questions and grading of knowledge

\begin{tabular}{|c|c|c|c|c|c|c|c|c|}
\hline & \multirow[t]{2}{*}{ Question } & \multirow{2}{*}{$\begin{array}{c}\text { Open/ close } \\
\text { ended } \\
\text { question }\end{array}$} & \multicolumn{2}{|c|}{ Good } & \multicolumn{2}{|c|}{ Average } & \multicolumn{2}{|c|}{ Poor } \\
\hline & & & $\mathbf{N}$ & $\%$ & $\mathbf{N}$ & $\%$ & $\mathbf{N}$ & $\%$ \\
\hline \multirow[t]{6}{*}{1} & $\begin{array}{l}\text { Can you name } 4 \text { symptoms/signs of influenza/viral } \\
\text { fever }\end{array}$ & open & 66 & 68.0 & 26 & 26.8 & 5 & 5.2 \\
\hline & - $\quad$ Fever $(93.8 \%)$ & & & & & & & \\
\hline & - Cough $(60.8 \%)$ & & & & & & & \\
\hline & $<50 \%$ responders & & & & & & & \\
\hline & Blocked nose, Shortness of breath, Body aches, & & & & & & & \\
\hline & $\begin{array}{l}\text { Headache, Sore throat, Fatigue, loss of appetite, } \\
\text { wheezing, nausea \& vomiting, sneezing, chest pain, } \\
\text { vertigo, chills, tachycardia }\end{array}$ & & & & & & & \\
\hline 2 & $\begin{array}{l}\text { During which months of the year do influenza } \\
\text { outbreaks occur }\end{array}$ & open & 57 & 58.8 & - & - & 40 & 41.2 \\
\hline 3 & $\begin{array}{l}\text { Is it a mild disease or does it have complications that } \\
\text { could lead to death? }\end{array}$ & close & 81 & 83.5 & - & - & 16 & 16.5 \\
\hline \multirow[t]{5}{*}{4} & $\begin{array}{l}\text { Who is at risk of severe complications from } \\
\text { influenza? }\end{array}$ & open & 24 & 24.7 & 38 & 39.2 & 35 & 36.1 \\
\hline & - Children $(74.2 \%)$ & & & & & & & \\
\hline & - $\quad$ Elderly $(74.2 \%)$ & & & & & & & \\
\hline & - $\quad$ Pregnant women $(59.8 \%)$ & & & & & & & \\
\hline & - Chronic diseases $(45.4 \%)$ & & & & & & & \\
\hline \multirow[t]{6}{*}{5} & $\begin{array}{l}\text { Can you name } 3 \text { methods to prevent getting } \\
\text { influenza yourself }\end{array}$ & open & 17 & 17.5 & 38 & 39.2 & 42 & 43.3 \\
\hline & - $\quad$ Masks $(83.5 \%)$ & & & & & & & \\
\hline & - Washing hands $(73.2 \%)$ & & & & & & & \\
\hline & - Avoid patients $(53.6 \%)$ & & & & & & & \\
\hline & $<30 \%$ responders & & & & & & & \\
\hline & $\begin{array}{l}\text { Avoid touching patients, not sharing utensils or } \\
\text { personal items, vaccine, wear gloves, disinfection, } \\
\text { isolate }\end{array}$ & & & & & & & \\
\hline \multirow[t]{4}{*}{6} & Name 3 methods of transmission of influenza virus & open & 9 & 9.2 & 36 & 37.1 & 52 & 53.6 \\
\hline & - Droplets $(96.9 \%)$ & & & & & & & \\
\hline & $<30 \%$ responders & & & & & & & \\
\hline & Airborne, contact with objects, contact with infected & & & & & & & \\
\hline \multirow[t]{6}{*}{7} & $\begin{array}{l}\text { Can you name } 3 \text { measures to adopt that would } \\
\text { prevent transmission to others }\end{array}$ & open & 46 & 47.4 & 40 & 41.2 & 11 & 11.3 \\
\hline & - Face masks $(86.6 \%)$ & & & & & & & \\
\hline & - Washing hands after coughing $(46.4 \%)$ & & & & & & & \\
\hline & $\begin{array}{l}\text { - Covering nose } \& \text { mouth when coughing or } \\
\text { sneezing }(41.2 \%)\end{array}$ & & & & & & & \\
\hline & $<20 \%$ responders & & & & & & & \\
\hline & $\begin{array}{l}\text { Not spitting, wiping respiratory secretions off } \\
\text { surfaces, not sharing utensils or personal items, } \\
\text { isolate, avoid crowds }\end{array}$ & & & & & & & \\
\hline 8 & Is there any medication for Influenza? & close & 60 & 61.9 & - & - & 37 & 38.1 \\
\hline 9 & What are those medications? & open & 42 & 43.3 & - & - & 18 & 18.6 \\
\hline 10 & Is there a vaccine for influenza? & close & 72 & 74.2 & - & - & 25 & 25.8 \\
\hline 11 & How often does the vaccine need to be given? & open & 5 & 5.2 & - & - & 67 & 69.1 \\
\hline
\end{tabular}


Knowledge on influenza transmission was poor in most $(n=52 ; 53.6 \%)$ but was average regarding preventive measures. Only seven (7.2\%) nurses mentioned influenza vaccine for prophylaxis and only $42(43.3 \%)$ knew that Oseltamivir was the drug of choice. The majority of the nurses $(74.2 \%)$ knew that an influenza vaccine was available but only five $(5.2 \%)$ knew it had to be taken annually. Overall knowledge was average in $53(55 \%)$ and a good level of knowledge was identified only in 33 (34\%) (Table 2).

\section{Attitude}

Most $(n=62 ; 63.9 \%)$ believed that the vaccine was safe and the majority $(n=77 ; 79.4 \%)$ would agree to be vaccinated if vaccination was free. However, 15/77 (19.5\%) were reluctant to be vaccinated annually. Barriers for vaccination were perceiving it as not essential $(n=6)$, doubts regarding efficacy $(n=4)$, fear of vaccines $(n=2)$, side effects $(n=2)$, and past influenza vaccination $(n=1)$ (Table $2 b)$.

Table $2 \mathrm{~b}$. Proportion of responses to questions and grading of attitudes and practices

\begin{tabular}{|c|c|c|c|c|c|c|c|c|}
\hline & \multicolumn{2}{|c|}{ Yes } & \multicolumn{2}{|c|}{ No } & \multicolumn{2}{|c|}{ Don't know } \\
\hline \multicolumn{2}{|c|}{ Factors lital antect altilude } & & \multirow{2}{*}{$\begin{array}{l}\mathbf{N} \\
3\end{array}$} & \multirow{2}{*}{$\begin{array}{l}\% \\
3.1\end{array}$} & \multirow{2}{*}{$\begin{array}{r}\mathbf{N} \\
84\end{array}$} & \multirow{2}{*}{$\begin{array}{r}\% \\
86.6\end{array}$} & \multirow{2}{*}{$\begin{array}{r}\mathbf{N} \\
10\end{array}$} & \multirow{2}{*}{$\begin{array}{r}\% \\
10.3\end{array}$} \\
\hline 12 & Have you ever had influenza? & close & & & & & & \\
\hline 13 & $\begin{array}{l}\text { Were there any complications/did you need } \\
\text { hospitalization following an attack of influenza? }\end{array}$ & close & 1 & 1.0 & 96 & 98.9 & - & - \\
\hline 14 & Do you suffer from a chronic illness & close & 11 & 11.3 & 86 & 88.7 & - & 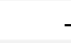 \\
\hline 15 & Do you think the vaccine is safe? & close & 62 & 63 & 9 & 9.3 & 26 & 26.8 \\
\hline 16 & $\begin{array}{l}\text { If the government provides the vaccine for free in the } \\
\text { future, would you be willing to take it? }\end{array}$ & close & 77 & 79.4 & 14 & 14.4 & 6 & 6.2 \\
\hline \multirow[t]{7}{*}{17} & Reason for not taking vaccine & open & & & & & & \\
\hline & $\circ$ perceiving it as not essential & & 6 & & & & & \\
\hline & o doubts regarding efficacy & & 4 & & & & & \\
\hline & $\circ$ fear of vaccines & & 2 & & & & & \\
\hline & $\circ \quad$ side effects & & 2 & & & & & \\
\hline & $\circ$ vaccinated in past & & 1 & & & & & \\
\hline & $\circ \quad$ No reason given & & 5 & & & & & \\
\hline 18 & $\begin{array}{l}\text { Influenza vaccine should be taken annually. Are you } \\
\text { willing to take it annually? }\end{array}$ & close & 65 & 67.0 & 29 & 29.9 & 3 & 3.1 \\
\hline \multicolumn{9}{|c|}{ Practices } \\
\hline 19 & If you were ill with viral fever would you go to work? & close & 58 & 59.8 & 39 & 40.2 & - & - \\
\hline 20 & Have you ever received the influenza vaccine? & close & 7 & 7.2 & 62 & 63.9 & 28 & 28.9 \\
\hline
\end{tabular}

\section{Practices}

Fifty eight $(59.8 \%)$ nurses claimed they would go to work despite being ill. Very few nurses $(\mathrm{n}=7 ; 7.2 \%)$ had been immunized for influenza (Table $2 \mathrm{~b})$.

\section{Discussion}

Poor knowledge regarding influenza and vaccines has been identified as a barrier for vaccination. ${ }^{4}$ Overall knowledge regarding influenza was average in our study. Nurses were knowledgeable about symptoms, consequences of influenza and had an average understanding of the high risk groups. Failure to identify HCWs as a risk group was notable. Despite responding poorly to the question on methods of transmission, nurses had an average level of knowledge on 
preventive measures. Studies have found that lack of awareness of the seriousness of influenza was a factor for low uptake of influenza vaccination. ${ }^{4}$ This is unlikely to be a factor in our study as most nurses were aware of its consequences.

In USA and Europe, the most stated reason for refusal of vaccines was the fear of side effects. ${ }^{5}$ However, most nurses in our study perceived the influenza vaccine as safe $(63.9 \%)$ and were willing to be immunized if it was given free. Only $5.2 \%$ were aware that annual vaccination was required and when apprised, willingness to vaccinate (79.4\%) decreased (69.1\%) (Table 2a).

Similar to our study, a study in West Java, Indonesia reported average knowledge but positive attitudes towards vaccination among nurses. ${ }^{6}$ Survey findings of HCWs consisting mainly of nurses from Saudi Arabia describes good knowledge and attitudes, probably resulting in high level of acceptance and uptake of the vaccine. ${ }^{7}$

Barriers for vaccination identified in our study were, the need for annual vaccination, belief that it was not essential, low efficacy, fear of vaccines and side effects. Similar to our study, poor perception of the usefulness of influenza vaccine has been consistently identified as a significant barrier to vaccine uptake in other surveys. ${ }^{4}$ Belief that risk of acquiring disease and severity of disease was low were other identified factors, but was not observed in our study. ${ }^{4}$ Fear of vaccine side effects were observed in both ours and previous studies. ${ }^{4}$ We did not look for associations as very few nurses had been immunized. Studies have shown that socio-demographic factors are inconsistent predictors of vaccine intent. ${ }^{4}$

Most nurses in our study (59.8\%) did not consider influenza an illness that warranted staying away from work, as reported previously. ${ }^{8}$ Very few (7.2\%) being immunized may be due to the vaccine not being provided free and not being mandatory in Sri Lanka. Similar low immunization rates $(7 \%)$ were found in Turkey, despite recommendations for regular vaccination and provision of vaccine free of charge. ${ }^{9}$ Due to the mandatory vaccination policies in the USA, immunization rates of HCWs reached $75.2 \%$ in $2013-2014 .{ }^{10}$ However, whether vaccination should be compulsory for HCWs is debatable.

\section{Conclusions}

Overall knowledge, attitudes and practices regarding influenza and vaccine needs to be improved in nurses. Misconceptions and fears need to be addressed if immunization programs are to be successful.

\section{Limitations}

Due to the country lockdown in March, data collection was interrupted and only 97 of the planned 199 participants could be recruited. Small sample size and very few nurses being immunized for influenza prevented us from looking for associations that affect vaccine intent. The duration of service and service in medical wards was not evaluated in this study.

Conflict of interest: There are no conflicts of interest 
Ethics statement: Ethics Review Committee, Faculty of Medical Sciences, University of Sri Jayewardenepura approved this study (Application No. CM/27/2019).

Acknowledgements: Special thanks to the participants for their cooperation and the hospital administrative staff for permission to conduct this study.

Self-funded study

\section{Author contributions}

WCRG, GEG, KPBG, ASH, SN contributed equally in the formulation of questionnaire, collection of data and data entry;

BCVS co-supervised the study

KMG was responsible for concept, co-supervision of study, analysis of data for publication, writing draft manuscript

All authors read and approved the article.

\section{References}

1. World Health Organization. Seasonal Influenza. Fact Sheet 2020. Available at: https://www.who.int/news-room/fact-sheets/detail/influenza-(seasonal). Accessed on 26.12.20

2. Medical Statistics Unit, Ministry of Health and Indigenous Medical Services, Colombo. Annual Health Statistics 2018, Sri Lanka. Available at:

http://www.health.gov.lk/moh_final/english/public/elfinder/files/publications/AHB/2020/Final\%20A HS\%202018.pdf. Accessed on 26.12.20

3. Ryan J, Zoellner Y, Gradl B et al. Establishing the health and economic impact of influenza vaccination within the European Union 25 countries. Vaccine. 2006; 24(47-48):6812-6822. doi: doi.org/10.1016/j.vaccine.2006.07.042

4. Schmid P, Rauber D, Betsch $\mathrm{C}$ et al. Barriers of influenza vaccination intention and behavior - A systematic review of influenza vaccine hesitancy, 2005-2016. PLoS One 2017; 12(1):e0170550. doi:10.1371/journal.pone.0170550

5. Ozisik L, Tanriover MD, Altınel S et al. Vaccinating healthcare workers: Level of implementation, barriers and proposal for evidence-based policies in Turkey. Hum Vaccin Immunother. 2017; 13(5):1198-1206. doi: doi.org/10.1080/21645515.2016.1269992

6. Ramadhani BP, Soeroto AY, Suryadinata H, Rakhmilla LE. Nursing knowledge, attitude, and practice to influenza vaccination at suburban hospital in West Java, Indonesia. J Prev Med Hyg 2020; 61:E15-E20. doi: https://doi.org/10.15167/2421-4248/jpmh2020.61.1.1119

7. Alshammari TM, Yusuff KB, Aziz MM, Subaie GM. Healthcare professionals' knowledge, attitude and acceptance of influenza vaccination in Saudi Arabia: a multicenter cross-sectional study. BMC Health Serv Res. 2019; 19:229. doi: https://doi.org/10.1186/s12913-019-4054-9

8. Chiu S, Black C, Yue X et al. Working with influenza-like illness: Presenteeism among US health care personnel during the 2014-2015 influenza season. Am J Infect Control. 2017; 45(11): 12541258. doi:10.1016/j.ajic.2017.04.008

9. Tumturk A, Tosun S, Y1ldiz IE et al. Seasonal influenza vaccination coverage: a multicenter crosssectional study among healthcare workers. Ortadogu Tip Derg. 2020; 12(1): 113-119. doi: doi.org/10.21601/ortadogutipdergisi.658876

10. Black CL, Yue X, Ball SW et al. Influenza vaccination coverage among health care personnel United States, 2016-17 Influenza Season. MMWR Morb Mortal Wkly Rep. 2017; 66(38):1009-1032. https://www.cdc.gov/mmwr/volumes/66/wr/pdfs/mm6638al.pdf 